European Journal of Accounting, Auditing and Finance Research

Vol.8, No.4, pp.89-111, April 2020

Published by ECRTD-UK

Print ISSN: 2053-4086(Print), Online ISSN: 2053-4094(Online)

\title{
RESPONSIBILITY ACCOUNTING AND CORPORATE INVESTMENT DECISIONS AMONG LISTED MANUFACTURING FIRMS IN NIGERIA
}

\author{
Yisa. A. Adeniji, Prof. Ishola. R. Akintoye, Dr. Folajimi, F. \\ Babcock University, Department of Accounting, Ilishan Remo \\ Ogun State, Nigeria. \\ Corresponding Author's email_Adeniji.adeniyi@gmail.com
}

\begin{abstract}
Over the years, corporate and institutional investors had suffered huge financial losses because of poor or wrong investment decisions taken based on manipulated financial information. Studies have shown globally that the practice of financial report misrepresentation commonly leads to loss of credibility, integrity and confidence in accounting information and the earnings become questionable. This situation now calls for additional sources of information that would enhance the quality of corporate investment decision. This study investigated the impact of responsibility accounting adoption on corporate investment decisions in selected listed manufacturing companies in Nigeria. The study adopted survey research designs with a population of 54 listed manufacturing companies in Nigeria. Purposive sampling technique was used to select 510 respondents from a sample frame of 34 companies. A structured questionnaire was used to collect data validated using Cronbach Alpha with Coefficient ranging from 0.772 to 0.907 with 97.2\% response rate. The data were analyzed and validated using descriptive and inferential statistics. The study found that responsibility accounting had significant influence on corporate investment decisions (Adj. $R^{2}=0.425, R^{2}=0.429, F_{(5474)}=120.747 ; p<0.001$ ). The study concluded that responsibility accounting influences corporate investment decisions for different stakeholders in selected listed manufacturing company in Nigeria. The study recommended that investors and decision makers alike should consider and monitor the organizational structure, manager's responsibility power, budgetary control system, performance report and reward system in addition to the audited financial statement when embarking on corporate investment decisions. KEYWORDS: corporate investment decisions, listed manufacturing firms, responsibility accounting.
\end{abstract}

\section{INTRODUCTION}

Over the years, both local and multinational establishments were collapsing without any prior indications. Corporate and institutional investors had suffered huge financial losses because of poor or wrong investment decisions taken based on manipulated financial information. The reason for this ugly situation was not too difficult to identify. As Akintoye (2019), documented the list of financial scandals among Nigerian Companies to include: Cadbury (2006) N13.25billions, Afrobank (2006) N6.9billions, Oceanic Bank (2010) N150billions, Bank PHB (2011) N25.7billions, Access Bank (2011) \$19millions or N6.84billions, Intercontinental Bank (2012) N400billions, and Skye Bank (2018) N126billions (Bakre, 2007; Ebhodaghe, 1996; CBN, 1997; Ifeanyi, 2011). On September $24^{\text {th }}, 2018$ the federal government of the federation through the intervention of the Central Bank of Nigeria (CBN) rescued the depositor's funds, by converting the Skye Bank Plc to 
European Journal of Accounting, Auditing and Finance Research

Vol.8, No.4, pp.89-111, April 2020

Published by ECRTD-UK

Print ISSN: 2053-4086(Print), Online ISSN: 2053-4094(Online)

Polaris Bank Plc. (CBN, 2018) The demise of Oceanic Bank Plc, Bank PHB Plc, Intercontinental Banks Plc, Mainstream Bank Plc, Savannah Bank Plc, Credite Bank Plc, and Enterprise Bank are still fresh in investor's memory. In the year 2019, both the Access Bank Plc and the Diamond Bank Plc merged into one corporate entity. While the public are being told that the move is a merger decision, investors, saw the move as an acquisition decision by the management of Access Bank Plc. The challenges being faced by the investors based on investigation is the level of reliance on the audited financial statement of listed companies in Nigeria.

Healy and Palepu (2003) opined that the corporate failure that were observed in different parts of the globe were dependent on the lack of adequacy in the information disclosure and the decision made were based on biased information where the management team purposively and wrongly misrepresent the financial information. Since those failures especially that of Worldcom, Enron and Anderson in the USA, brought changes in the financial reporting regulation that fundamentally requires full disclosure of financial and non-financial information in order to improve the quality of information for decision making. Till date, the problems of creative accounting still persist resulting in the clamor for voluntary disclosure of financial information. Freeman, (2010); Valipour and Moradbeygi, (2011); Venazi, (2012) observed that practice of financial information manipulations to depict firms profitability has yielded distrust and apathy in most financial systems. This situation now calls for additional sources of information that will enhance meaningful corporate investment decision.

The management accounting plays a major role in any business establishment by providing the needed information towards assisting management in areas of planning, controlling, decision making and performance evaluation. For several decades, the improvement in modern technology, globalization, stiffer competition among corporations has encouraged much demands for information that is accurate on a timely basis (Nawaiseh, Zeidan, Falahat \& Qtish, 2014).According to Gadave (2017) several reasons are responsible for the increased demand for the adoption of responsibility accounting across various establishments both small and large. In the past, a lot of factors such as technological advancements, merger and acquisitions, diversification decisions and high rate of competition has made effective management of enterprise operation a bit challenging and difficult (Gadave, 2017).Although, accounting branches are many such as social responsibility accounting, forensic accounting, environmental accounting, management accounting, cost accounting, and financial accounting, responsibility accounting is not a branch of accounting (Ritika, 2015). Responsibility accounting is an information system that classifies data according to areas of responsibility and reports each areas of activities separately (Owino, 2017). The reports include the revenues, costs and resources that the assigned managers have absolute control on (Drury, 1996, 2004).

In Nigeria, corporate investment decisions are generally premised on financial reporting (Omokkudu \& Ibadin, 2015) with specific emphasis on investors' interest using quantitative variables such as earnings quality, accrual quality, earnings management and accounting conservatism against return on equity or earnings per share as indicated. Other studies such as Abolaji and Adeolu (2015); Ahmed and Duellman (2011); Chan-Jane, Tawei and Chae-Jung (2015); Chidiebere (2013); Ciao-Wei, Daniel, Collins, Kravet and Margenthaler (2018) used 
Vol.8, No.4, pp.89-111, April 2020

Published by ECRTD-UK

Print ISSN: 2053-4086(Print), Online ISSN: 2053-4094(Online)

qualitative variables of relevance, faithful representations, comparability, timeliness, understandability and verifiability of financial information against companies performance and dividend policy to justify the reliance of audited financial statements as a key component of investment decisions. However the problems of corporate failure persists both in Nigeria and elsewhere, while corporate and institutional investors continue to loose substantial amount due to the manipulation of financial statement. This situation now calls for additional sources of information that would enhance the quality of corporate investment decision. This research work therefore makes a bold attempt towards investigating the applicability of responsibility accounting in the field of corporate investment decisions.

\section{Objective of the study}

The main objective of this study was to examine the effect of responsibility accounting practices on corporate investment decisions among selected listed manufacturing firms in Nigeria. The specific objectives were to:

1. evaluate the effect of organizational structure on corporate investment decisions in selected listed manufacturing firms in Nigeria;

2. examine the effect of managers responsibility powers on corporate investment decisions in selected listed manufacturing firms in Nigeria;

3. investigate the impact of budgetary control system on corporate investment decisions in selected listed manufacturing firms in Nigeria;

4. ascertain how performance report affect corporate investment decisions in selected listed manufacturing firms in Nigeria;

5. establish how reward system affect investment decisions among selected listed manufacturing firms in Nigeria and

6. evaluate the effects of responsibility accounting system on corporate investment decision among selected listed manufacturing firms in Nigeria.

\section{Research Hypotheses}

The following hypotheses were tested in this study at 0.05 level of significance.

$\mathrm{HO}_{1}$ : Organizational structure does not have significant effect on corporate investment decisions in selected listed manufacturing firms in Nigeria.

$\mathrm{HO}_{2}$ : Managers responsibility powers do not have significant effect on corporate investment decisions among selected listed manufacturing firms in Nigeria.

$\mathrm{H}_{3}$ : Budgetary control systems do not have significant effect on corporate investment decisions among selected listed manufacturing firms in Nigeria.

$\mathrm{H}_{4}$ : Performance report does not have significant impact on corporate investment decisions among selected listed manufacturing firms in Nigeria

$\mathrm{H}_{5}$ : There is no significant effect of reward system on corporate investment decision in selected manufacturing firms in Nigeria

$\mathrm{HO}_{6}$ : Responsibility accountings have no significant combined effect on corporate investment decisions among selected listed manufacturing firms in Nigeria. 
European Journal of Accounting, Auditing and Finance Research

Vol.8, No.4, pp.89-111, April 2020

Published by ECRTD-UK

Print ISSN: 2053-4086(Print), Online ISSN: 2053-4094(Online)

\section{LITERATURE REVIEW}

Responsibility accounting is the collection, summarization and reporting of financial information about various decision centres (responsibility centres) throughout an organization (Fakir, Islam \& Miah, 2014). It is also referred to activity accounting or profitability accounting (Horngren, Dater \& Rajan, 2016). According to Owino, Munene and Ntayi (2017), responsibility accounting is an administrative accounting method which deals with costs and revenue performance, used in measuring the results of all responsibility centres where performance of the managers are evaluated based on activities under their control.Generally, there are many views about the responsibility accounting system, according to different objectives, professional, researchers or administrators in different establishments. Each consider the concept from different angle, however, there is no unified concept of responsibility accounting (Trans, 2017).

At the time of industrial revolution more and more companies turned to the mass production to manage large capacities and to control costs and revenues of this separated business units, responsibility accounting became a widespread concept (Drury, 2006). The concept of responsibility accounting occurred in the first half of the twentieth century after the conclusion of the Second World War as a key development in the field of cost accounting (Kahala \& Hanan, 2002). However, to gain the benefits associated with the responsibility accounting, is the issue of size and specialization. Other significant factors that led to the slow embrace of this concept at the initial stage was the companies' attitudes towards forming a big economic unit, establishing different branches in different cities and increase the competition between the companies and the multiple administrative levels (Razi, 2007). However, Gadave (2017) argued that activities of major competitors, frequent changes in the level of technology, diversification of investment and market innovations complicated business operations in the past and these factors necessitated the need for responsibility accounting.

Responsibility accounting is centered on "economic models" of decision-making and their adoption promises increased efficiency and effectiveness of organizational performance (Baker, 2003) from agency relationships. Agency relationship in this case, refers to fiduciary relations which results from the manifestation of consent by one person (principal) to another, that the other person (agent) shall perform on his behalf and is subject to his control and consent by the other to perform (Owino, 2017). Responsibility accounting helps manager to have valuable information in making decisions for achieving general objectives and strengthen sustainable development of enterprises (Tran, 2017). As posited by Fakr, Islam, and Ntayi (2017), responsibility accounting represents a system of collection, summarization and report on accounting information related to costs, income and operating data by each scope of responsibility or unit in organization. Such system shall provide information so as to evaluate responsibility and performance of each manager. Responsibility accounting shall create reports containing objective which are either controllable or non-controllable for a management level. Responsibility accounting is viewed by Meda (2003) as the management method designed as an accounting system which obtain control efficiency through the direct relationship between accounting report at the head of the organizational structure of company at all management levels. Responsibility accounting connects 
European Journal of Accounting, Auditing and Finance Research

Vol.8, No.4, pp.89-111, April 2020

Published by ECRTD-UK

Print ISSN: 2053-4086(Print), Online ISSN: 2053-4094(Online)

the personal performance report with the heads of the different management levels, to determine the level of obtaining goal of management and responsibility centres. These responsibility centres have different goals and use resources of company to obtain the goals (Rajbi, 2004). Sarker and Yeshmim (2005) opined that an appropriate control mechanism which serves as a veritable avenue to management for effective information that will assist in both short and long range decision making is the responsibility accounting system.

As elaborated above from various scholars, responsibility accounting can be described as a management accounting tools designed mainly to provide segmental information to assist in the managerial functions of planning, controlling, decision making and effective performance evaluation (Pajrok, 2014). Although, several well-known experts in the field of accounting favoured the controllability principle but the concept of responsibility accounting is all encompassing as positioned by the following writers. Hongren, Datar and Rajan (2016) explains that responsibility accounting is a system of accounting that recognizes various responsibility centre throughout the organization and reflects the "plans" and actions of each of these centres by assigning particular revenue and costs to the one having the pertinent responsibility.

Biswas (2017) observed that responsibility accounting is a system of finding out a causal relationship between activities and performance of that activities so that divisional performance can be easily evaluated through effective decentralization. In the opinion of Tran (2017), responsibility accounting helps manager to control and evaluate activities conducted by departments of a firm and evaluate different levels of management responsibilities. Responsibility accounting is one of the crucial tools for today's managers in making decision of managing, operating and controlling business activities (Tran, 2017). However, if the doctrine associated with responsibility accounting are at variance with the perception of top managers, executives, and the divisional managers then the system is bound to be less effective (Gadave, 2017). Conclusively, Kermit and Barbara in Owino, Munene and Ntayi (2016) observed that successful implementation of responsibility accounting in any organization requires four (4) major steps namely, establishing responsibility centres, establishing performance measures, evaluating performance, and defining reward system. Owino, et al.,(2016) claimed that responsibility accounting is an administrative accounting method which deals with costs and revenues performance, and also used in measuring the results of all responsibility centres where performance of the managers is evaluated based on the things which are under their control. They conducted cross-sectional survey in order to find out if the concepts of responsibility accounting are being applied among Ugandan Public Universities. Their findings clearly indicate that responsibility accounting follows hierarchal patterns. Zheng and Wang (2018) embarked on a study designed to investigate the impact of the previously acquired knowledge of an enterprise on the development of new product. To achieve this objective, the researcher, constructed a stackelberg game model using secondary data among selected manufacturing companies. It was discovered that knowledge spillover from previous product development influences investment decision relating to the development of new product. Although it is logical to conclude that knowledge resources is a qualitative aspect of responsibility accounting, the study did not mention responsibility accounting in any way. 
European Journal of Accounting, Auditing and Finance Research

Vol.8, No.4, pp.89-111, April 2020

Published by ECRTD-UK

Print ISSN: 2053-4086(Print), Online ISSN: 2053-4094(Online)

Chokeli (2015) examined the impact of the organizational design in evaluating the company's success in Georgia. Using triangulation research design, questionnaire was used to obtain data from forty-eight (48) companies while face-to-face interview were coordinated on the staff of twenty (20) companies. Through descriptive analysis, findings reveal that legal barriers, taxes, currency variability, unstable environment and management are key factors influencing the success or failure of any organization. In addition, the effectiveness of any establishment will be measured through, strategic vision and goals, organizational structure, personnel, strategy, organizational culture, technology and leadership style. Fakir, Islam and Miah (2014) investigated the impact of adopting responsibility accounting among the garment manufacturer in Bangladesh. The researchers adopted survey research design utilizing non-probabilistic sampling to circulate the structured questionnaire in obtaining the required primary data. Descriptive and inferential statistics revealed that the adoption of responsibility accounting is satisfactory in all the listed garment industries investigated.

Tasnim (2018) investigated the impact of organizational structure and analysis on the smooth operation of Apple Group. The researcher adopted triangulation research design and obtain primary data through personal interview with Apple employees. Secondary data were also adopted to validate the position of the primary data. Findings indicated that Apple group adopts a flat and organic structure where authorities are centralized from the top down the ladder. As a result of the culture of internal secrecy, much of the organizational activities are not published. Though, the researcher did not consider the effect of organizational structure on responsibility accounting, it is obvious that without an organizational structure, decision-making organogram is not feasible.

Gadave (2017) examined the concept of responsibility accounting within the context of performance reporting. Using an exploratory research design, the researcher critically evaluate the concept of RA by identifying the reasons for its current wide spread adoption together with the basic requirements. The researcher concluded by identifying the various responsibility centres, management support and cost control through responsibility accounting. However, since the study is not empirical in nature, it failed to relate RA with any aspect of managerial function such as planning, controlling, decision-making or performance evaluation. Zimnicki (2016) discussed extensively the rationale for RA being regarded as an inspiration for segment reporting. Based on literature analysis, the researcher traced the historical background of RA from the twentieth century to the period of centralization, decentralization and divisionalized structure. Responsibility centres was also classified into four major areas such as cost, revenue, profit and investment centres. Again, even though the analysis is detailed, it lacked empirical analysis to support any position. Bai, Feng, Yue and Feng (2017) investigated the effect of the adopted organizational structure on the performances of a new product development team using cross-functional integration associated with the team as the intermediary variable. Using survey research design to obtain relevant data from the manufacturing and high technology industry in China. The result of the multilever linear model indicates that the specific features of an enterprise organogram significantly affect the development of new product. However, cross-sectional data was adopted for this research, the result from time series data is yet to be obtained and this represents a major gap in this research. 
European Journal of Accounting, Auditing and Finance Research

Vol.8, No.4, pp.89-111, April 2020

Published by ECRTD-UK

Print ISSN: 2053-4086(Print), Online ISSN: 2053-4094(Online)

Efni (2017) investigated the mediating effect of investment decisions and financing decisions on the impact of corporate value. The population adopted was the property and real estate sectors quoted on the Indonesia stock exchange for a period of nine years that is from 2001-2008 using secondary data. Based on descriptive and inferential analysis, the study observed that only the investment decisions and the company's risk are the two variables that will increase the net worth of any company. On the other hand, financing decisions and dividend policy are not able to increase the market value. Even though, the study is limited to the real sector, effect of responsibility accounting on investment decisions were not considered. Biswas (2017) embarked on comprehensive review of related literature on responsibility accounting adoption by different types of establishment. The study adopted a descriptive and exploratory design coupled with secondary data to analyze the associated benefits of implementing responsibility accounting system. Findings revealed a direct relationship between company activities and performance. In addition, the concept of responsibility accounting will facilitate effective control and managerial decisions including corporate investment decisions. The study is however, not empirical in nature and as such not directly related to any specific establishment or environment. Owino (2017) examined the adoption of the responsibility accounting concept among the various universities in Uganda considering agency relation. Using cross sectional survey design comprising of both qualitative and quantitative data to examine the hypothesis. Findings revealed that agency theory is significantly related to responsibility accounting concept and that appropriate authorities are obtained at the departmental levels before preparing the actual budget. This research work is restricted to the academic sector of the economy and may not be directly appropriate within the private sector even in the same environment.

Tran (2017) investigated the adoption of responsibility accounting concept to sustainable development among the Vietnamese manufacturing firms. Based on the survey research design, with a sample size of 64 and using structured questionnaire as a research instrument to obtain relevant data from managers and head of department of textile and garment manufacturers. Based on the result provided by SPSS (22), findings revealed that the adoption of responsibility accounting is at different stages and not necessarily at the same level. The study however, did not relate responsibility accounting with the corporate investment decision. Rani and Rani (2015) stated that the size of organization determines whether the structure of it should be centralized or decentralized along with defining responsibility accounting system, which is necessary in terms of delegation of responsibilities and authorities where the managers are made to be responsible for planning and controlling the business activities. They also added that, comparing each responsibility centre's standard data with actual data, organization's performance result can be either favourable or unfavourable where the greater actual data than that of standard, the favourable the result would be, and vice- versa. Allahverdi, (2014) observed that with the current development of business throughout the world, where organizations need to adopt new technologies along with different strategies for the attainment of the organizational objectives. He opined that today's business must change its structure, with new methodology about the centrifugal administration in business where decision making authority is delegated from higher administration units to lower ones which leads to the increase in the importance of responsibility accounting in business. 
European Journal of Accounting, Auditing and Finance Research

Vol.8, No.4, pp.89-111, April 2020

Published by ECRTD-UK

Print ISSN: 2053-4086(Print), Online ISSN: 2053-4094(Online)

Akembor and Nwaiwu (2013) conducted a research where responsibility accounting is a system with which performance of different segments are evaluated. For attaining their goal, they developed research questions, formulated hypothesizes and reviewed related literature. As research instrument they made questionnaire which population consists a sample of 32 accountants in Rivers State of the manufacturing industry. The collected data was analyzed using descriptive statistics and the hypotheses were based on chi-square test. The study evaluated that the responsibility accounting is not at all suitable for segment performance on specific manufacturing firms. The researcher suggested that to take the challenge facing responsibility accounting, adequate effort would be needed by organizational executives. They suggest that effectiveness can be achieved by developing market capitalization of those companies, providing enough and skilled manpower and ensuring current data collection about cost, profit investment of the Nigerian company. Nyakuwanika et al.,(2012) conducted a study relating to an analysis of effective responsibility accounting system strategies in the Ministry of Health and Child Welfare (MOHCW) in Mashonaland West province of Zimbabwe where sample of 70 employees from fourteen stations using systematic and purposive sampling methods. This study observed planning and control were not integrated among the departments where the performance reports were not distributed among the sectional managers on a regular basis.

\section{Justification for the Study}

Generally, previous literature provides evidence that corporate investment decisions are universally influenced by various factors among which are corporate risk and dividend (Efni, 2017), knowledge spillover level (Zheng \& Wang, 2018), financial statement analysis (Anaja \& Onoja 2015, Vestine, Kule\& Mbabazize, 2016)stock market valuation (Azarmi \& Schmidt, 2016), earnings management (Julio \& Yook, 2016), political uncertainty (Riem, 2016), cashflow sensitivity (Basty, 2016), interest rate (Ibi, Offiong \& Udofia, 2015), corporate governance (Bistrova, Lace \& Travonaviene, 2015), survival and replacement of worn-out assets (Pevic \& Durkin, 2015), macroeconomics and law-related factors (Bialowalski, \& Weziak-Bialowolski, 2014), capital structure (Arafat, Warokka \& Suryasaputra, 2014) but not on responsibility accounting. Literature that dealt with responsibility accounting were only focusing on its effect on sustainable development (Tran, 2017), segment reporting (Zimnicki, 2016), organizational structure (Mojgan, 2012; Ritika, 2015), segment performance (Akembor \& Nwaiwu, 2013), and profit planning (Ocansey \& Enahoro, 2012). Thus, this study hopes to expand the frontier of knowledge by adopting quantitative measures in evaluating the effect of responsibility accounting on corporate investment decisions among selected listed manufacturing companies in Nigeria.

\section{METHODOLOGY}

The study adopted survey research design to gather data. Survey method was adopted to collect primary data from the respondents. The study focused on manufacturing organizations registered and quoted by the Nigeria stock exchange (NSE). From the total population of fifty four (54) quoted manufacturing firms, a sample of thirty four (34) firms were purposively selected for data collection spread across five (5) industries comprising Conglomerates, consumer goods, health care, industrial goods and natural resources. The sampling frame comprises of the top management, members of the accounting and finance division together with respondents from the 
Vol.8, No.4, pp.89-111, April 2020

Published by ECRTD-UK

Print ISSN: 2053-4086(Print), Online ISSN: 2053-4094(Online)

firm of external auditors. The study used quantitative approach by measuring respondents' view on a graduated scale for statistical analysis in order to have a reasonable accurate measurement of the constructs rather than using observation. Data were collected mainly from primary sources and analyzed using descriptive and inferential statistics.

\section{Operationalization of Variables}

For the use of primary data, the following models functions were developed

$\mathrm{Y}=f(\mathrm{x})$

$\mathrm{y}=$ Dependent variable

$\mathrm{x}=$ Independent variable

$\mathrm{y}=$ Corporate Investment Decisions (CID)

$\mathrm{x}=$ Responsibility Accounting (RA)

$\therefore \mathrm{CID}=f(\mathrm{RA})$

$\mathrm{X}=\left(\mathrm{x}_{1}, \mathrm{x}_{2}, \mathrm{x}_{3}, \mathrm{x}_{4}\right.$ and $\left.\mathrm{x}_{5}\right)$

$\mathrm{x}_{1}=$ ORS $=$ Organizational structure

$\mathrm{x}_{2}=\mathrm{MRP}=$ Managers Responsibility Power

$\mathrm{x}_{3}=\quad \mathrm{BUD}=$ Budgetary Control System

$\mathrm{x}_{4}=\quad \mathrm{PRT}=$ Performance Report

$\mathrm{x}_{5}=\mathrm{RWS}=$ Reward System

$\mathrm{y}=$ Corporate investment decisions

From these formulated variables and sub-variables formulated as the proxies to measure the major variables, the study set the following functional relationships to test the research objectives using primary data.

Functional Relationship

$\mathrm{CID}=f(\mathrm{ORS})-$ Equation 1

$\mathrm{CID}=f(\mathrm{MRP})-$ Equation 2

$\mathrm{CID}=f(\mathrm{BUD})-$ Equation 3

$\mathrm{CID}=f(\mathrm{PRT})-$ Equation 4

$\mathrm{CID}=f(\mathrm{RWS})-$ Equation 5

$\mathrm{CID}=f(\mathrm{ORS}, \mathrm{MRP}, \mathrm{BUD}, \mathrm{PRT}, \mathrm{RWS})-$ Equation 6

\section{RESULTS AND DISCUSSION OF FINDINGS}

Table 4.1 Summary of Statistics of Responsibility Accounting and Corporate Investment Decisions

\begin{tabular}{|l|l|l|l|l|}
\hline Category & N & Mean & S.D & Remark \\
\hline Organizational structure & 486 & 4.13 & 0.53 & Agreed \\
\hline Manager's responsibility power & 486 & 4.08 & 0.57 & Agreed \\
\hline Budgetary control & 486 & 4.08 & 0.52 & Agreed \\
\hline Performance report & 486 & 4.05 & 0.53 & Agreed \\
\hline Reward system & 486 & 4.04 & 0.59 & Agreed \\
\hline Corporate Investment Decision & 486 & 4.06 & 0.60 & Agreed \\
\hline
\end{tabular}

Source: Field Survey, 2019 
European Journal of Accounting, Auditing and Finance Research

Vol.8, No.4, pp.89-111, April 2020

Published by ECRTD-UK

Print ISSN: 2053-4086(Print), Online ISSN: 2053-4094(Online)

\section{Interpretation}

The results indicate that in general, organizational structure was perceived to be the most crucial variable in responsibility accounting system with a mean of 4.13 on a point of 5 . Each of the managers' responsibility power and budgetary control system also gave similar value. The mean values were 4.08 for both manager's responsibility power and budgetary control system respectively. Performance report and reward system had a marginally lower mean value of 4.05 and 4.04 respectively. On the average, the respondents generally and strongly agreed with the views that organization structure, managers' responsibility power, budgetary control system performance report and reward system are key components of responsibility accounting system among selected listed manufacturing companies in Nigeria.

\section{Relationship among the variables}

Table 4.2 Correlation Coefficient

\begin{tabular}{|l|l|l|l|l|l|l|}
\hline Variables & Mean & S.D & N & r & P & Remark \\
\hline Corporate Investment Decision (\%) & 76.55 & 14.88 & 486 & & & \\
\hline Organizational structure (\%) & 78.16 & 13.26 & 486 & 0.60 & $<0.001$ & Sig \\
\hline Managers Responsibility power (\%) & 76.90 & 14.31 & 486 & 0.47 & $<0.001$ & Sig \\
\hline Budgetary Control System (\%) & 76.89 & 12.91 & 486 & 0.54 & $<0.001$ & Sig \\
\hline Performance Report (\%) & 76.32 & 13.14 & 486 & 0.55 & $<0.001$ & Sig \\
\hline Reward System (\%) & 75.96 & 14.69 & 486 & 0.34 & $<0.001$ & Sig \\
\hline
\end{tabular}

\section{Source: Field Survey, 2019}

Objective 1: To evaluate the effect of organizational structure on corporate investment decisions in selected listed manufacturing companies in Nigeria;

Interpretation: Table 4.2 shows that corporate investment decisions rated $76.55 \%$ ( $s d=14.88 \%$ ) and organizational structure rated $78.16 \%(s d=13.26 \%)$. The correlation coefficient reveals that there is a strong positive and significant relationship between corporate investment decision and organizational structure in listed manufacturing companies in Nigeria $(r=0.60, p<0.05)$. This implies that the better the organizational structure in place, the better the corporate investment decision of listed manufacturing companies in Nigeria.

Objective 2: To examine the effect of managers responsibility powers on corporate investment decisions in selected listed manufacturing companies in Nigeria;

Interpretation: Table 4.2 shows that corporate investment decisions rated $76.55 \%(s d=14.88 \%)$ and Managers responsibility powers rated $76.90 \%$ ( $s d=14.31 \%$ ). The correlation coefficient reveals that there is a weak but positive and significant relationship between corporate investment decision and managers responsibility powers in listed manufacturing companies in Nigeria $(r=$ 0.47, $p<0.05)$. 
European Journal of Accounting, Auditing and Finance Research

Vol.8, No.4, pp.89-111, April 2020

Published by ECRTD-UK

Print ISSN: 2053-4086(Print), Online ISSN: 2053-4094(Online)

Objective 3: To investigate the impact of budgetary control system on corporate investment decisions in selected listed manufacturing companies in Nigeria;

Interpretation: Table 4.2 shows that corporate investment decisions rated $76.55 \%(\mathrm{sd}=14.88 \%)$ and budgetary control rated $76.89 \%(\mathrm{sd}=12.91 \%)$. The correlation coefficient shows that there is a strong, positive and significant relationship between corporate investment decision and budgetary control in listed manufacturing companies in Nigeria $(r=0.54, p<0.05)$. The implication is that when estimates budgets of listed manufacturing companies increases, their corporate investment decisions will equally increase and vice versa.

Objective 4: To ascertain how performance report affects corporate investment decisions among selected listed manufacturing companies in Nigeria;

Interpretation: Table 4.2 shows that the mean of corporate investment decisions rating is $76.55 \%$ $(\mathrm{sd}=14.88 \%)$ and the mean of performance report rating is $76.32 \%(\mathrm{sd}=13.14 \%)$. The correlation coefficient reveals that there is a strong, positive and significant relationship between corporate investment decision and performance report in listed manufacturing companies in Nigeria $(r=$ $0.55, p<0.05)$. The implication is that when listed manufacturing companies improve on the performance reports, their corporate investment decisions will equally improve.

Conversely, if performance report is not giving the adequate attention it deserves in an organization then, the attribute of corporate investment decisions will decline.

Objective 5: To establish how reward systems affect investment decisions among selected listed manufacturing companies in Nigeria;

Interpretation: Table 4.2 shows that the mean corporate investment decisions rating is $76.55 \%$ ( $\mathrm{sd}=14.88 \%)$ and the mean reward system rating is $75.96 \%(\mathrm{sd}=14.69 \%)$. The correlation coefficient reveals that there is a weak but positive and significant relationship between corporate investment decision and reward system in listed manufacturing companies in Nigeria $(r=0.55, p$ $<0.05)$. The implication is that when companies improve their reward system, their corporate investment decisions will equally improve. On the other hand, a decline in the reward system of an organization will also elicit a downward trend in corporate investment decisions.

\section{Test of Hypotheses}

This section tests the hypotheses stated for the study on the relative and combined effect of the independent variables (organizational structure, managers' responsibility powers, budgetary control system among responsibility centres, performance report and reward system) on corporate investment decisions at $5 \%$ level of significance. Both correlation coefficient and regression model were adopted in testing the hypotheses. Correlation coefficient was to establish the relationship among the variables while regression model will examine the effect of each variable on corporate investment decisions.

Objective 1: To evaluate the effect of organizational structure on corporate investment decisions in selected listed manufacturing companies in Nigeria. 
European Journal of Accounting, Auditing and Finance Research

Vol.8, No.4, pp.89-111, April 2020

Published by ECRTD-UK

Print ISSN: 2053-4086(Print), Online ISSN: 2053-4094(Online)

Research Hypothesis Ho1: Organizational structure does not have significant effect on corporate investment decisions in selected listed manufacturing companies in Nigeria

\section{Decision Rule:}

The rule was to accept null hypothesis if the p-value is greater than or equal to 0.050; otherwise accept the alternative hypothesis.

Table 4.3: Regression analysis of the relationship between organizational structure and corporate investment decision in listed manufacturing companies in Nigeria

\begin{tabular}{|l|l|l|l|l|l|l|l|}
\hline & & Std. & & & & Adj $\mathbf{R}^{\mathbf{2}}$ & $\mathbf{F}_{\mathbf{1 , 4 8 4}}=$ \\
Model & $\mathbf{B}$ & Error & $\mathbf{T}$ & Sig. & $\mathbf{R}^{\mathbf{2}}$ & & $272.978 ;$ \\
\hline Constant) & 23.887 & 3.233 & 7.389 & $<0.001$ & 0.361 & & $\mathrm{p}<0.001$ \\
\hline Organizational Structure & 0.674 & .041 & 16.522 & $<0.001$ & & 0.359 & \\
\hline
\end{tabular}

\section{Source: Field Survey, 2019}

The regression model of the effect of organizational structure on corporate investment decision in listed manufacturing companies in Nigeria is given as:

$\mathrm{CID}=\beta_{0}+\beta_{1}$ ORS $+\mu$

\section{CID $=23.887+0.674 *$ Organizational Structure}

The results show that organizational structure has positive relationship with corporate investment decisions in listed manufacturing companies in Nigeria. In addition, there is evidence that organizational structure has significant relationship with corporate investment decisions of the selected listed manufacturing firms in Nigeria $(\mathrm{ORS}=0.674, t$-test $=16.522, \mathrm{p}<0.05)$. This implies that organizational structure is a significant factor influencing changes corporate investment decisions of selected listed manufacturing firms in Nigeria. Concerning the magnitude of the estimated parameters, the coefficient is 0.674; this implies that a unit increase in the organizational structure will lead to 0.674 increases in corporate investment decisions of the selected manufacturing firms in Nigeria. The $\mathrm{R}^{2}$ which measures the proportion of the changes in corporate investment decisions as a result of changes in the organizational structure explains about 36 per cent changes in corporate investment decisions of listed manufacturing firms in Nigeria, while the remaining 64 per cent were other factors explaining changes in corporate investment decisions of selected manufacturing firms in Nigeria but where not captured in the model.

Therefore, the t-statistic of 16.522 is statistically significant with $\mathrm{p}<0.05$ indicating that the null hypothesis that organizational structure does not have significant effect on corporate investment decisions in selected listed manufacturing companies in Nigeria was rejected. Thus, the alternative hypothesis that organizational structure has significant effect on corporate investment decisions in selected listed manufacturing companies in Nigeria was accepted at 5 per cent level of significance.

Objective 2: To examine the effect of managers responsibility powers on corporate investment decisions in selected listed manufacturing companies in Nigeria; 
European Journal of Accounting, Auditing and Finance Research

Vol.8, No.4, pp.89-111, April 2020

Published by ECRTD-UK

Print ISSN: 2053-4086(Print), Online ISSN: 2053-4094(Online)

Research HypothesisHo2: Managers responsibility powers do not have significant effect on corporate investment decisions among selected listed manufacturing companies in Nigeria.

\section{Decision Rule:}

The rule was to accept null hypothesis if the p-value is greater than or equal to 0.050; otherwise accept the alternative hypothesis.

Table 4.4: Regression analysis of the relationship between managers' responsibility powers and corporate investment decision in listed manufacturing companies in Nigeria

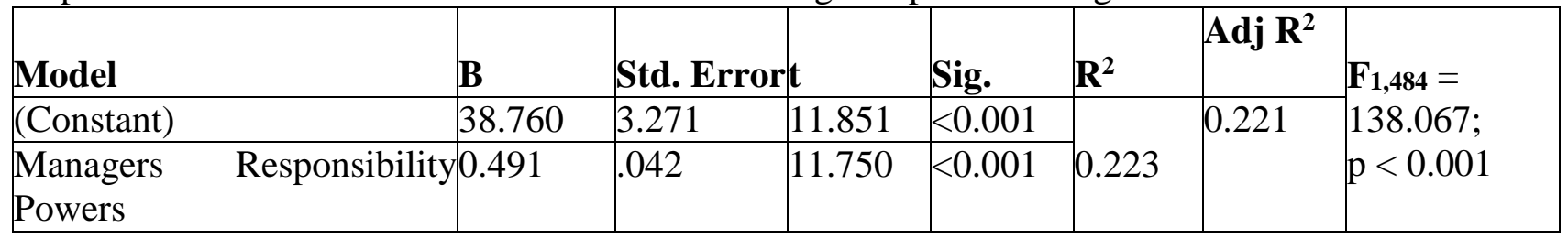

\section{Source: Field Survey, 2019}

The regression model of the effect of manager's responsibility powers on corporate investment decision in listed manufacturing companies in Nigeria is given as:

\section{$\mathrm{CID}=\beta_{0}+\beta_{1} \mathrm{MRP}+\mu$}

\section{CID $=38.760+0.491 *$ Managers Responsibility Powers}

The results show that manager's responsibility power has positive relationship with corporate investment decisions in listed manufacturing companies in Nigeria. In addition, there is evidence that manager's responsibility powers has significant relationship with corporate investment decisions of the selected listed manufacturing firms in Nigeria $(\mathrm{MRP}=0.491, t$-test $=11.750, \mathrm{p}<$ 0.05). This implies that manager's responsibility powers is a significant factor influencing changes corporate investment decisions of selected listed manufacturing firms in Nigeria.

Concerning the magnitude of the estimated parameters, the coefficient is 0.491 ; this implies that a unit increase in the manager's responsibility powers will lead to 0.491 increases in corporate investment decisions of the selected manufacturing firms in Nigeria. The $\mathrm{R}^{2}$ which measures the proportion of the changes in corporate investment decisions as a result of changes in the manager's responsibility powers explains about 22 per cent changes in corporate investment decisions of listed manufacturing firms in Nigeria, while the remaining 78 per cent were other factors explaining changes in corporate investment decisions of selected manufacturing firms in Nigeria but where not captured in the model.

Therefore, the t-statistic of 11.750 is statistically significant with $\mathrm{p}<0.05$ indicating that the null hypothesis that manager's responsibility powers does not have significant effect on corporate investment decisions in selected listed manufacturing companies in Nigeria was rejected. Thus, the alternative hypothesis that manager's responsibility powers has significant effect on corporate investment decisions in selected listed manufacturing companies in Nigeria was accepted at 5 per cent level of significance. 
European Journal of Accounting, Auditing and Finance Research

Vol.8, No.4, pp.89-111, April 2020

Published by ECRTD-UK

Print ISSN: 2053-4086(Print), Online ISSN: 2053-4094(Online)

Objective 3: To investigate the impact of budgetary control system on corporate investment decisions in selected listed manufacturing companies in Nigeria;

Research HypothesisHo3: Budgetary control system among responsibility centres do not have significant effect on corporate investment decisions among selected listed manufacturing companies in Nigeria.

\section{Decision Rule:}

The rule was to accept null hypothesis if the p-value is greater than or equal to 0.050; otherwise accept the alternative hypothesis.

Table 4.5: Regression analysis of the relationship between budgetary control system among responsibility and corporate investment decision in listed manufacturing companies in Nigeria

\begin{tabular}{|l|l|l|l|l|l|l|l|}
\hline Model & B & $\begin{array}{l}\text { Std. } \\
\text { Error }\end{array}$ & $\mathbf{T}$ & Sig. & $\mathbf{R}^{\mathbf{2}}$ & Adj R $^{\mathbf{2}}$ & $\mathbf{F}_{\mathbf{1}, 484}=$ \\
\hline Constant & 29.052 & 3.454 & 8.410 & $<0.001$ & 0.287 & 0.285 & $194.315 ;$ \\
\hline Budgetary Control & 0.618 & .044 & 13.940 & $<0.001$ & & & 0.001 \\
\hline
\end{tabular}

\section{Source: Field Survey, 2019}

The regression model of the effect of budgetary control on corporate investment decision in listed manufacturing companies in Nigeria is given as:

$\mathrm{CID}=\beta_{0}+\beta_{1} \mathrm{BUD}+\mu$

CID $=29.052+0.618 *$ Budgetary Control System

The results show that budgetary control system has positive relationship with corporate investment decisions in listed manufacturing companies in Nigeria. In addition, there is evidence that budgetary control system has significant relationship with corporate investment decisions of the selected listed manufacturing firms in Nigeria (BUD=0.618, $t$-test=13.940, $\mathrm{p}<0.05)$. This implies that budgetary control system is a significant factor influencing changes corporate investment decisions of selected listed manufacturing firms in Nigeria.

Concerning the magnitude of the estimated parameters, the coefficient is 0.618 ; this implies that a unit increase in the budgetary control system will lead to 0.618 increases in corporate investment decisions of the selected manufacturing firms in Nigeria. The $\mathrm{R}^{2}$ which measures the proportion of the changes in corporate investment decisions as a result of changes in the budgetary control system explains about 29 per cent changes in corporate investment decisions of listed manufacturing firms in Nigeria, while the remaining 71 per cent were other factors explaining changes in corporate investment decisions of selected manufacturing firms in Nigeria but where not captured in the model.

Therefore, the t-statistic of 13.940 is statistically significant with $\mathrm{p}<0.05$ indicating that the null hypothesis that budgetary control system does not have significant effect on corporate investment decisions in selected listed manufacturing companies in Nigeria was rejected. Thus, the alternative hypothesis that budgetary control system has significant effect on corporate investment decisions 
European Journal of Accounting, Auditing and Finance Research

Vol.8, No.4, pp.89-111, April 2020

Published by ECRTD-UK

Print ISSN: 2053-4086(Print), Online ISSN: 2053-4094(Online)

in selected listed manufacturing companies in Nigeria was accepted at 5 per cent level of significance.

Objective 4: To ascertain how performance reports affect corporate investment decisions in selected listed manufacturing companies in Nigeria;

Research HypothesisH04: Performance report does not have significant impact on corporate investment decisions among selected listed manufacturing companies in Nigeria.

\section{Decision Rule:}

The rule was to accept null hypothesis if the p-value is greater than or equal to 0.050; otherwise accept the alternative hypothesis.

Table 4.6: Regression analysis of the relationship between performance report and corporate investment decision in listed manufacturing companies in Nigeria

\begin{tabular}{|l|l|l|l|l|l|l|l|}
\hline Model & B & $\begin{array}{l}\text { Std. } \\
\text { Error }\end{array}$ & T & Sig. & $\mathbf{R}^{\mathbf{2}}$ & Adj R & F $\mathbf{1 , 4 8 4}=$ \\
\hline Constant) & 29.227 & 3.335 & 8.765 & $<0.001$ & 0.300 & 0.298 & $207.346 ;$ \\
\hline Performance Report & 0.620 & .043 & 14.400 & $<0.001$ & & & \\
\hline
\end{tabular}

Source: Field Survey, 2019.

The regression model of the effect of performance report on corporate investment decision in listed manufacturing companies in Nigeria is given as:

\section{$\mathrm{CID}=\beta_{0}+\beta_{1}$ PRT $+\mu$}

\section{CID $=29.227+0.620 *$ Performance Report}

The results show that performance report has positive relationship with corporate investment decisions in listed manufacturing companies in Nigeria. In addition, there is evidence that performance report has significant relationship with corporate investment decisions of the selected listed manufacturing firms in Nigeria (PRT $=0.620, t$-test $=14.400, p<0.05)$. This implies that performance report is a significant factor influencing changes corporate investment decisions of selected listed manufacturing firms in Nigeria.

Concerning the magnitude of the estimated parameters, the coefficient is 0.620 ; this implies that a unit increase in the performance report will lead to 0.620 increases in corporate investment decisions of the selected manufacturing firms in Nigeria. The $\mathrm{R}^{2}$ which measures the proportion of the changes in corporate investment decisions as a result of changes in the performance report explains about 30 per cent changes in corporate investment decisions of listed manufacturing firms in Nigeria, while the remaining 70 per cent were other factors explaining changes in corporate investment decisions of selected manufacturing firms in Nigeria but where not captured in the model.

Therefore, the t-statistic of 14.440 is statistically significant with $\mathrm{p}<0.05$ indicating that the null hypothesis that performance report does not have significant effect on corporate investment decisions in selected listed manufacturing companies in Nigeria was rejected. Thus, the alternative 
European Journal of Accounting, Auditing and Finance Research

Vol.8, No.4, pp.89-111, April 2020

Published by ECRTD-UK

Print ISSN: 2053-4086(Print), Online ISSN: 2053-4094(Online)

hypothesis that performance report has significant effect on corporate investment decisions in selected listed manufacturing companies in Nigeria was accepted at 5 per cent level of significance.

Objective 5: To establish how reward system affects investment decisions among selected listed manufacturing companies in Nigeria.

Research HypothesisHo5: There is no significant effect of reward system on corporate investment decision in selected manufacturing companies in Nigeria

\section{Decision Rule:}

The rule was to accept null hypothesis if the p-value is greater than or equal to 0.050; otherwise accept the alternative hypothesis.

Table 4.7: Regression analysis of the relationship between reward system and corporate investment decision in listed manufacturing companies in Nigeria

\begin{tabular}{|c|c|c|c|c|c|c|c|}
\hline Model & B & $\begin{array}{l}\text { Std. } \\
\text { Error }\end{array}$ & $\mathbf{T}$ & Sig. & $\mathbf{R}^{2}$ & Adj $R^{2}$ & \multirow{3}{*}{$\begin{array}{l}\mathbf{F}_{\mathbf{1}, \mathbf{4 8 4}}=62.928 \\
\mathrm{p}<0.001\end{array}$} \\
\hline (Constant) & 50.293 & 3.365 & 14.946 & $<0.001$ & \multirow{2}{*}{0.116} & 0.114 & \\
\hline Reward System & .345 & .043 & 7.933 & $<0.001$ & & & \\
\hline
\end{tabular}

\section{Source: Field Survey, 2019}

The regression model of the effect of reward system on corporate investment decision in listed manufacturing companies in Nigeria is given as:

$\mathrm{CID}=\beta_{0}+\beta_{1} \mathrm{RWS}+\mu$

$\mathrm{CID}=\mathbf{5 0 . 2 9 3}+0.345 *$ Reward System

The results show that reward system has positive relationship with corporate investment decisions in listed manufacturing companies in Nigeria. In addition, there is evidence that reward system has significant relationship with corporate investment decisions of the selected listed manufacturing firms in Nigeria $(\mathrm{RWS}=0.345, t$-test $=7.933, \mathrm{p}<0.05)$. This implies that reward system is a significant factor influencing changes corporate investment decisions of selected listed manufacturing firms in Nigeria.

Concerning the magnitude of the estimated parameters, the coefficient is 0.345 ; this implies that a unit increase in the reward system will lead to 0.345 increases in corporate investment decisions of the selected manufacturing firms in Nigeria. The $\mathrm{R}^{2}$ which measures the proportion of the changes in corporate investment decisions as a result of changes in the reward system explains about 12 per cent changes in corporate investment decisions of listed manufacturing firms in Nigeria, while the remaining 88 per cent were other factors explaining changes in corporate investment decisions of selected manufacturing firms in Nigeria but where not captured in the model.

Therefore, the t-statistic of 7.933 is statistically significant with $\mathrm{p}<0.05$ indicating that the null hypothesis that reward system does not have significant effect on corporate investment decisions 
in selected listed manufacturing companies in Nigeria was rejected. Thus, the alternative hypothesis that reward system has significant effect on corporate investment decisions in selected listed manufacturing companies in Nigeria was accepted at 5 per cent level of significance.

Objective 6: To evaluate the combined effects of the five (5) components of responsibility accounting system on corporate investment decision among selected listed manufacturing firms in Nigeria.

Research Hypotheses Ho6: Organizational structure, manager's responsibility powers, budgetary control system, performance report and reward system have no significant combined effect on corporate investment decisions among selected manufacturing firms in Nigeria.

\section{Decision Rule:}

The rule was to accept null hypothesis if the p-value is greater than or equal to 0.050; otherwise accept the alternative hypothesis.

Table 4.8: Effect of Responsibility Accounting on Corporate Investment Decisions in Listed Manufacturing Companies in Nigeria

\begin{tabular}{|c|c|c|c|c|}
\hline Model & B & Std. Error & $\mathbf{T}$ & Sig. \\
\hline Constant & 11.377 & 3.680 & 3.092 & 0.002 \\
\hline Organizational Structure (ORS) & 0.408 & 0.056 & 7.279 & $<0.001 *$ \\
\hline Managers Responsibility Powers (MRP) & 0.027 & 0.052 & 0.514 & 0.608 \\
\hline Budgetary Control (BUD) & 0.229 & 0.057 & 3.999 & $<0.001 *$ \\
\hline Performance Report (PRT) & 0.218 & 0.065 & 3.357 & $0.001 *$ \\
\hline Reward System (RWS) & -0.038 & 0.044 & -0.858 & 0.391 \\
\hline \multicolumn{5}{|c|}{$R^{2}=0.427 ;$ Adj. $R^{2}=0.421 ; F_{5,474}=70.625 ; p<0.001$} \\
\hline
\end{tabular}

\section{Source: Field Survey, 2019}

The regression model of the combined effect of all independent variables on corporate investment decision in listed manufacturing companies in Nigeria is given as:

\section{$\mathrm{CID}=\beta_{0}+\beta_{1}$ ORS $_{\mathrm{i}}+\beta_{2} \mathrm{MRP}_{\mathrm{i}}+\beta_{3} \mathrm{BUD}_{\mathrm{i}}+\beta_{4} \mathrm{PRT}_{\mathrm{i}}+\beta_{5} \mathrm{RWS}_{\mathrm{i}}+\mu$ \\ $\mathrm{CID}=11.373+0.408 * O R S+0.027 * \mathrm{MRP}+0.229 * \mathrm{BUD}+0.218 * P R T-0.038 * R W S$}

Table 4.8 shows the results of regression analysis for the effect of responsibility accounting on corporate investment decisions in listed manufacturing companies in Nigeria. The results show that organizational structure, managers responsibility powers, budgetary control and performance report have positive relationship with corporate investment decisions in listed manufacturing companies in Nigeria, while reward system has negative relation with corporate investment decisions in listed manufacturing companies in Nigeria In addition, there is evidence that organizational structure, budgetary control and performance report have significant relationship with corporate investment decisions in listed manufacturing companies in Nigeria $(\mathrm{ORS}=0.408$, $T$ - test $=7.279, \mathrm{p}<0.05, \mathrm{BUD}=0.229, T$ - test $=3.999, \mathrm{p}<0.05, \mathrm{PRT}=0.218 T$ - test $=3.357, \mathrm{p}<$ 0.05). This implies that organizational structure, budgetary control and performance report are 
significant factors influencing changes in the corporate investment decisions in listed manufacturing companies in Nigeria. Conversely, managers responsibility powers and reward system do not have significant relation with corporate investment decisions in listed manufacturing companies in Nigeria $(\mathrm{MRP}=0.027, T$ - test $=0.514, \mathrm{p}>0.05, \mathrm{RWS}=-0.038, T$ - test $=-0.858, \mathrm{p}>$ 0.05). This implies that manager's responsibility powers and reward system were not significant factors influencing changes in corporate investment decisions in listed manufacturing companies.

Concerning the magnitude of the estimated parameters for the coefficients are $0.408,0.027,0.229$, 0.218 and -0.038 . This implies that a unit increase in organizational structure, managers responsibility powers, budgetary control and performance report level will lead to $0.408,0.027$, 0.229 and 0.218 increase in corporate investment decisions in listed manufacturing companies in Nigeria respectively, while a unit increase in reward system will lead to decrease of 0.038 in corporate investment decisions in listed manufacturing companies in Nigeria.

The Adjusted $\mathrm{R}^{2}$ measures the proportion of the changes in corporate investment decisions in listed manufacturing companies in Nigeria as a result of changes in organizational structure, managers responsibility powers, budgetary control, performance report and reward system explains about 42 per cent changes in corporate investment decisions in listed manufacturing companies in Nigeria, while the remaining 58 per cent were other factors explaining changes in corporate investment decisions in listed manufacturing companies in Nigeria but were not captured in the model.

The F- test of 70.625 is statistically significant with $p<.005$ indicated that the variables used in the model have a goodness of fit and that is a good predictor of the main variables and that organizational structure, managers responsibility powers, budgetary control, performance report and reward system jointly explains changes in corporate investment decisions in listed manufacturing companies in Nigeria. The F-statistic of 70.625 is statistically significant with $\mathrm{p}<$ 0.05 indicating that on the overall, the statistical significance of the model showed that the null hypothesis that organizational structure, manager's responsibility powers, budgetary control system, performance report and reward system have no significant combined effect on corporate investment decisions among selected manufacturing firms in Nigeria was rejected. Thus, the alternative hypothesis that organizational structure, manager's responsibility powers, budgetary control system, performance report and reward system have significant combined effect on corporate investment decisions among selected manufacturing firms in Nigeria was accepted at 1 per cent level of significance.

\section{Implication of Findings}

The findings of this study have implications to investors, employees, government agencies, customers, lenders and creditors, regulators and researchers. The study has revealed that quantitative measurement used in this study have informed that responsibility accounting adoption has significant effect on corporate investment decisions in listed manufacturing companies in Nigeria. The findings informed the policy measures that can be taken by management and regulators in pushing manufacturing companies providing quality based information for the purpose of effective investment decision making. 
Vol.8, No.4, pp.89-111, April 2020

Published by ECRTD-UK

Print ISSN: 2053-4086(Print), Online ISSN: 2053-4094(Online)

Shareholders and prospective investors are provided with the information from this study, that responsibility accounting reporting are that responsibility accounting reporting are imperative for their decision making in terms of additional investment or new investment and the contribution of their businesses to different stakeholders. Employees are provided with information that responsibility accounting is strategic to their decision making in terms of their employment, carrier advancement and its sustainability.

The regulators, especially the Nigeria Stock Exchange is provided with information about responsibility accounting reporting from selected listed manufacturing companies and their contribution to governmental value creation in terms of taxes and other levies that allow federal and state government in Nigeria to get financial capacity to support its social and economic development. NSE is provided with the findings that would assist in deepening the capital market operations through appropriate investment decisions. Thus, the findings would help in closing the information asymmetric gap between the shareholders (principal) and the management (agent) this study would therefore, move the capital market operations towards the path of perfection through the dissemination of quality information to stock market operators.

The study revealed to management of listed companies the effect of individual component of responsibility accounting on investment decisions. The importance of such concept as the organizational structure, manager's responsibility power, budgetary control system, performance report and reward system together with their effect on investment decision are broadly highlighted. Additionally, the study empirically observed that variable such as the organizational structure, budgetary control system, and performance report are more significant in influencing corporate investment decisions unlike the manager's responsibility power and reward system.

To the researchers, the study provides additional literature in the field of responsibility accounting and investment decision. This work is arguably the first to examine the applicability of adopting responsibility accounting concept in corporate investment decision among the listed manufacturing companies in Nigeria.

To policy formulators, this study provides an insight to all the stakeholders about the need for management to always present responsibility accounting report apart from the conventional financial accounting report. This position is premised on the fact that, responsibility accounting report is more far-reaching in terms of the information content. Additionally, such report will facilitate effective planning, control apart performance evaluation apart from the corporate investment decisions.

\section{CONCLUSION AND RECOMMENDATIONS}

The study examined the effect of responsibility accounting on corporate investment decisions in listed manufacturing companies in Nigeria. The findings from the study provide relevant empirical evidence by showing that organizational structure, managers responsibility powers, budgetary control system, performance report and reward system have significant effects on corporate investment decisions. The implications of the effect of responsibility accounting adoption on 
European Journal of Accounting, Auditing and Finance Research

Vol.8, No.4, pp.89-111, April 2020

Published by ECRTD-UK

Print ISSN: 2053-4086(Print), Online ISSN: 2053-4094(Online)

corporate investment decisions were given statistical and empirical fundamentals considered useful for policy and strategy formulations. Therefore, the study concluded that:

i) Organizational structure has strong, significant and positive effect on corporate investment decisions in listed manufacturing companies in Nigeria;

ii) Managers responsibility powers has weak, but positive significant effect on corporate investment decision in listed manufacturing firms in Nigeria;

iii) Budgetary control system has a strong, positive and significant influence on corporate investment decisions among listed manufacturing companies in Nigeria.

iv) Performance reports exert strong, positive and significant effect on corporate investment decisions among listed manufacturing companies in Nigeria.

v) Reward system has strong, positive and significant influence on corporate investment decisions in Nigeria's listed manufacturing firms.

The study recommended that corporate and institutional investors and other decisions makers alike should consider and monitor the organizational structure, manager's responsibility power, budgetary control system, performance report and the company's reward systems in addition to the audited financial statement when embarking on corporate investment decisions.

\section{REFERENCES}

Abolaji, O. B. \& Adeolu, O. O. (2015). Perceived effects of international financial reporting standards (IFRS) adoption on quality financial reporting of quoted companies in Nigeria. Research Journal of Finance and Accounting, 6(23), 1-8.

Ahmed, A. S. \& Duellman, S. (2011). Evidence on the role of accounting conservatism in monitoring managers' investment decisions. Accounting and Finance, 51(3), 609-633.

Ajagbe M.A. (2007). The Impact of Strategic Planning on Effectiveness of Marketing Operations: Case of NEPA. An Unpublished MBA Thesis Submitted to the Graduate School, Ambrose Ali University, Ekpoma, Nigeria.

Akembor, C. O. \& Nwaiwu, J. N (2013). The effectiveness of responsibility accounting in evaluating segment performance of manufacturing firms. KASU Journal of Accounting Research and Practice. 2(2), 103-112.

Akintoye, I.R. (2019). Accounting: A Mismanaged Concept Requiring Urgent Re-definition. $28^{\text {th }}$ Inaugural Lecture, Babcock University.

Arya, A., Glover, J., \& Radhakrishman, S. (1998). The Controllability Principle in Responsibility Accounting. Another look: Retrieved from http://wenku.baidu.com/view

Atu, O. O. K., Ogbeide, E., Agbo, I. S. \& Ozele, C. E. (2014). Responsibility Accounting: An Overview. IOSR Journal of Business and Management. 16(1), 73-79.

Azarmi, T. \& Schmidt (2016). Determinants of Corporate Investments: Theory and Evidence on the Investment Effect of Corporate Taxes. Accounting and Business Research, 46(7), 731759.

Baker, C.R. (2003). Theoretical Approaches to MICS, in proceeding of the Annual Conference of the Administrative Sciences of Association of Canada Critical Accounting Research Track, edited by Normal Macintosh, 25(3), 283-299.

Bakre, O.M. (2007). The Unethical Practices of Accountants and Auditors and the Compromising Stance of Professional Bodies in the Corporate Nigeria: Accounting Forum, 31(3), 277303. 
European Journal of Accounting, Auditing and Finance Research

Vol.8, No.4, pp.89-111, April 2020

Published by ECRTD-UK

Print ISSN: 2053-4086(Print), Online ISSN: 2053-4094(Online)

Basty, N. (2016). Corporate investment and cashflow sensitivity: Evidence from a Jasmin revolution period in Tunisia market. Asian economic and financial review. 6(11), 634-646.

Bialowolski, P. \& Weziak-Bialowolska, D. (2014).External factors affecting investment decisions of companies. Economics: The Open-Access, Open-Assessment E-Journal, 8 (1),1-21.

Bistrova, J., Lace, N. \& Tvaronaviciene, M. (2015).Corporate governance as a factor for investment decision making on CEE equity markets. The 15th world multi-conference on systemics, cybernetics and informatics proceedings. 1, 59-64.

Biswas, T. (2017). Responsibility Accounting: A review of related literature. International Journal of Multidisciplinary Research and Development. 4(8), 202-206.

Budiarso, N. S., Mandey, S. L. \& Karamoy, H. (2018). Testing of agency and stewardship theories on financial accountability in Sulawesi region, Indonesia. International Journal of Finance and Accounting, 7(1), 13-18.

CBN (1997). Financial Sector Distress in CBN Briefs. Research Department, 97(1), 12.

Chan-Jane, L., Tawei, W. \& Chae-Jung, P. (2015). Financial reporting quality and investment decisions for family firms. Asia Pacific Journal of Management, 1(1), 1-34.

Chidiebere, M. E. (2013). Reliance on published financial statements and investment decision making in the Nigeria banking sector. European Journal of Accounting Auditing and Finance Research, 1(4), 67-82.

Ciao-Wei, C., Collings, W.D., Kravet, T. D. \& Mergenthaler, R. D. (2018).Financial statement comparability and the efficiency of acquisition decisions. Contemporary Accounting Research, 34(4), 1299-1310.

Demiski, J.S. \& Sappington, D.E. (1989). Hierarchal Structure and Responsibility Accounting. Journal of Accounting Research. 27(1), 40-51.

Don, R.H., \& Marynne, M.M. (2005).Management Accounting. McGraw-Hill Companies. Inc.

Drury, C. (1996). Management and Cost Accounting (4 ${ }^{\text {th }}$ Edition) International Thomson Business Press London.

Ebhodaghe, J.U. (1996). Distress Management and Prevention Strategies for the Nigerian Banking System. NDIC Quarterly, 6(3), 19-36.

Efni, Y. (2017). The mediating effect of investment decisions and financing decisions on the effect of corporate risk and dividend policy against corporate value. Investment Management and Financial Innovations. 14(2), 27-37.

Eisenhardt, K.M. (1989). Agency Theory: An Assessment and Review. The Academy of Management Review, 14(1), 57-74.

Enoma, A. \& Mustapha, I. (2010).Factor analysis of investment decision in Nigerian insurance companies. Interdisciplinary Journal of Contemporary Research in Business, 2(8), 108120.

Fakir, A. N. M. A., Islam, M. Z \& Miah M. S. (2014). The use of responsibility accounting in garments industry in Bangladesh. Journal of business studies. 1(2), 1-15.

Freeman, R. E (2011). Some thoughts on the development of stakeholder theory. In R. Phillips (Ed.) Stakeholder Theory: 25 Years Later, 212-233. Cheltenham, UK: Edward Elgar Publishing.

Gadave, B. R. (2017). Glimpses on Responsibility Accounting and Reporting. Imperial Journal of Interdisciplinary Research (IJIR). 3(2); 22-28 
European Journal of Accounting, Auditing and Finance Research

Vol.8, No.4, pp.89-111, April 2020

Published by ECRTD-UK

Print ISSN: 2053-4086(Print), Online ISSN: 2053-4094(Online)

Gharayba, Fatena, Debi, Ma'Moon, \& Nasar, A. (2011). The extent of applying the elements of responsibility accounting in the industrial shareholding companies and its effect on the company's profitability and operational efficiency. Administrative Sciences. 38(1), 219234.

Gimenez P.A.F. (2000). The Benefits of a Coherent Strategy for Innovation and Corporate Change: A Study Applying Miles and Snow's Model in the Context of Small Firms Strategy and Innovation in SMEs. 9(4), 235-244.

Greenberg, J. (2011). Behavior in Organizations (10 ${ }^{\text {th }}$ Edition) Upper Saddle River, NE Prentice Hall.

Healy, P. M \& Palepu, G. K. (2003).The fall on Enron. Journal of Economic Perspectives, 17(2), 3-26.

Ifeanyi, D. (2011). "Corporate Governance and Bank Failure in Nigeria: Issues, Challenges and Opportunities". Research Journal of Finance and Accounting, 2(2), 1-18.

Jagongo, A. \& Mutswenje, V. S. (2014). A survey of the factors influencing investment decisions: The case of individual investors at the NSE. International Journal of Humanities and Social Science. 4, 92-102.

Jensen, M. C. \& Meckling, W. H. (1976). Theory of the firm: Managerial behavior, agency costs, and ownership structure. Journal of Financial Economics, 3(4), 305-360.

Kermit, D.L. and Barbara, C. (1996). Fundamental Accounting Principles (14 ${ }^{\text {th }}$ Edition) Chicago, IL: Richard Irwin Time Mirror Higher Education Group.

Maduenyi, S., Oke, A. O. \& Ajagbe, M. A. (2015).Impact of organizational structure on organizational performance. International conference on African development issues: social and economic models for development track.354-358.

Mintzberg H. (2009). Tracking Strategies: Toward a general theory of strategy formation. New York, NY Oxford University Press.

Mitnick, B. M. (1975). The theory of agency: The policing paradox and regulatory behavior. Public Choice (Winter), 24(1), 27-42.

Mojgan, S. (2012).Examining the role of responsibility accounting in organizational structure. American Academic \& Scholarly Research Journal. 4(5), 12-22

Nikkinen, J. \& Sahstrom, P. (2004). Does agency theory provide a general framework for audit pricing? International Journal of Auditing, 8(3), 253-262.

Omokhudu, O. O. \& Ibadin, O. P. (2015). The value relevance of accounting information: evidence from Nigeria. International Journal of Finance and Accounting, 5(3), 165-176.

Pajrok, A. (2014). Responsible accounting in the hospitality industry. Journal of Education Culture and Society. 1(2); 53-60.

Parnell J. \& Wright, P. (1993). Generic Strategy and Performance: An Empirical Test of the Miles and Snow Typology British Journal of Management, 1(1); 29-36.

Pevic, M. \& Durkin, J. (2015). Determinants of investment decisions in a crisis: perspective of Croatians small firms. Management, 20(1), 115-133.

Rani, R. \& Rani, M. (2015).The role of responsibility accounting in organizational structure, international journal of science, technology and management. 41(1), 185-190.

Riem, M. (2016).Corporate investment decisions under political uncertainty. Ifo Working Paper, No. 221, Leibniz Institute for Economic Research at the University of Munich, Munich. 
European Journal of Accounting, Auditing and Finance Research

Vol.8, No.4, pp.89-111, April 2020

Published by ECRTD-UK

Print ISSN: 2053-4086(Print), Online ISSN: 2053-4094(Online)

Ritika, M. R. (2015). The role of responsibility accounting in organizational structure. International Journal of Science, Technology and Management, 4(1), 185-190.

Shilpa, G. (2014). Responsibility Accounting practices in India. 2nd International Conference on Multidisciplinary Research \& Practice. 3(1), 373-378.

Sungun, G. (2015). Capital investment decisions in small and medium sized enterprises in Turkey. European Journal of Accounting, Auditing and Finance Research. 3(1), 46-55.

Thomas S.A. \& Ramaswamy R. (1996). Matching Managers to Strategy: Further Tests of Miles and Snow Typology British Journal Management, 7(1), 247-261.

Tran, T. T. (2017). Application Responsibility Accounting to Sustainable Development in Vietnam Manufacturers: An Empirical Study. Economics World. 5(6), 573-583.

Valipour, H \& Moradbeygi, M. (2011). Corporate debt financing and earning quality. Journal of Applied finance \& Banking, 1(3), 139- 157

Venazi, D. (2012). Financial performance measures and value creation. Journal of Art 1(1), 9 13.

Vestine, M., Kule, J. W., \& Mbabazize, M. (2016).Effect of financial statement analysis on investment decision making. A case of bank of Kigali. European Journal of Business and Social Sciences. 1 (5), 279-303.

Williams, S.M., Ho, W.P., \& Carol, A. (1999). Corporate Social Disclosures by Listed Companies on their Web-sites: AN International Comparison. The International Journal of Accounting, Elsevier, 34(3), 389-419.

Zarnowitz, V. (1992).Rational Expectations and Macroeconomic Forecasts. In Zarnowitz V. Ied.), Business Cycles: Theory, History, Indicators, and Forecasting, 1(1), 462-491)

Zheng, J. \& Wang, Y. (2018). Research on Knowledge Resources Investment Decisions in Cooperated New Product Development. Journal of Service Science and Management, 11(1), 101-115.

Zimnicki, T. (2016).Responsibility accounting inspiration for segment reporting. Copernican Journal of Finance \& Accounting, 5(2), 219-232. 